\title{
Formy polodowcowe atrakcją geoturystyczną Doliny Pięciu Stawów Polskich
}

Post-glacial forms as geotouristic attractions of the Five Ponds Valley, the Tatra Mts.

\author{
Paulina Mrowczyk, Grzegorz Madeja, Marek Doktor \\ Wydziat Geologii, Geofizyki i Ochrony Środowiska, \\ Akademia Górniczo-Hutnicza w Krakowie, Al. Mickiewicza 30, 30-059 Kraków \\ e-mails:mrowczyk@geol.agh.edu.pl,madeja@geol.agh.edu.pl,doktor@geol.agh.edu.pl
}
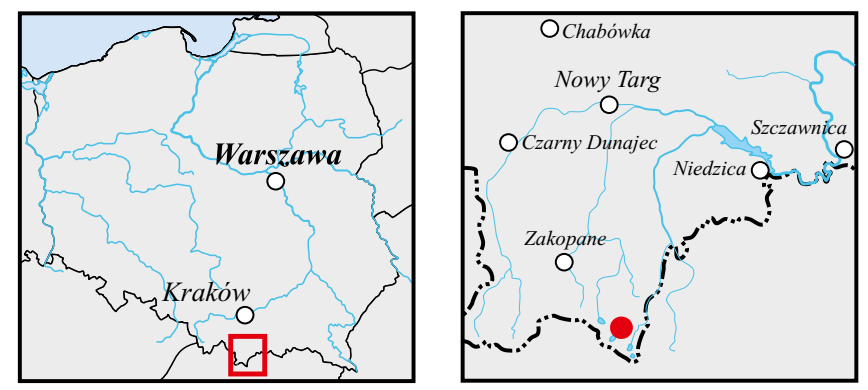

Treść: Trzynaście tysięcy lat temu, wraz z ocieplaniem się klimatu pod koniec würmu, na obszarze Doliny Pięciu Stawów Polskich rozpoczęła się deglacjacja. Po ustapieniu lodowca odstonity się formy powstałe zarówno w wyniku erozyjnej, jak i akumulacyjnej działalności lodowca. Należa do nich: kotty polodowcowe, misy i niecki, fosylne formy lodowców gruzowych, mutony i wygłady, a także moreny i rynna wód proglacjalnych. $W$ artykule krótko scharakteryzowano wyżej wymienione formy, zwracajac uwage na ich atrakcyjność jako obiektów geoturystycznych.

Slowa kluczowe: Tatry, Dolina Pięciu Stawów Polskich, zlodowacenie würm, lodowce górskie, lodowce gruzowe, kotty polodowcowe, waty niwalne, mutony.

Abstract: Thirteen thousand years ago, at the end of the Würm glacial epoch deglaciation has started in the Five Ponds Valley of the Polish Tatras due to global warming episode. After retreat of glaciers numerous post-glacial, erosional and depositional landforms have been exposed: cirques, bowls and troughs, fossiled rock glaciers, roches mountonées and polished surfaces as well as moraines and proglacial channel. The aim of the following paper is to describe post-glacial forms in the valley as attractive geotouristic objects.

Key words: Tatra Mountains, Five Ponds Valley of the Polish Tatras, Würm glacial epoch, mountain glaciers, rock-glaciers, cirques, nival moraines, roches mountonées.

\section{Wstęp}

Tatry jako górotwór o charakterze alpejskim na terenie Polski corocznie odwiedza ponad dwa miliony turystów. Przyciągają one zarówno niepowtarzalną rzeźbą, ale także bogactwem występującej tu flory i fauny. O ich niezwykłości może świadczyć fakt, że już ponad pół wieku temu teren ten został objęty ochroną prawną w formie parku narodowego.

Głównym czynnikiem, mającym wpływ na ukształtowanie obecnej rzeźby Tatr, były istniejące na tym terenie w okresie plejstocenu dolinne lodowce górskie. Objęły one swym zasięgiem 50\% powierzchni Tatr Wysokich oraz 21\% Tatr Zachodnich. Lodowce Tatr Zachodnich były dwukrot- nie krótsze od lodowców Tatr Wysokich, w których największą długość - 14 km osiągnął lodowiec Doliny Białki (Mojski, 2005).

Doskonałym przykładem doliny, w której zachowały się czytelne formy polodowcowe jest niewątpliwie Dolina Pięciu Stawów Polskich leżąca w samym sercu polskiej części Tatr Wysokich. Na jej obszarze wyróżnić można szereg form: począwszy od ogromnych rozmiarów kotłów polodowcowych, poprzez fosylne formy lodowców gruzowych, misy i niecki obecnie wypełnione przez wody stawów, wały moren czołowych aż do form mniejszych, takich jak mutony czy wygłady lodowcowe.

\section{Zarys budowy geologicznej Tatr}

Tatry powstały w wyniku orogenezy alpejskiej jako efekt napierania na siebie płyt kontynentalnych: afrykańskiej na europejską. Zostały sfałdowane i częściowo wypiętrzone w kredzie górnej, a ich główne wydźwignięcie nastąpiło po oligocenie (Bac-Moszaszwili, 1992).

Główną jednostką tektoniczną Tatr jest trzon krystaliczny, który obejmuje zarówno Tatry Wysokie jak i Tatry Zachodnie. Na obszarze Tatr Wysokich jest on zbudowany głównie z karbońskich granitów, natomiast trzon Tatr Zachodnich to przede wszystkim gnejsy dewońskie i karbońskie (Mapa Geologiczna Tatr Polskich, 1979; Atlas Tatrzańskiego Parku Narodowego, 1985).

Na północnych zboczach trzonu krystalicznego leży autochton wierchowy, zbudowany głównie z piaskowców kwarcytowych (Passendorfer, 1983). Do niej przylega nasunięta seria wierchowa, na którą składa się płaszczowina Czerwonych Wierchów oraz płaszczowina Giewontu. Obie płaszczowiny zbudowane są głównie z węglanowych skał mezozoicznych (Passendorfer, 1983).

Z serią wierchową od północnej strony kontaktuje seria reglowa, którą także budują węglanowe utwory mezozoiczne, a w jej skład wchodzą płaszczowiny reglowa dolna (Kriźniańska) i reglowa górna (Choczańska) (Mapa Geologiczna Tatr Polskich, 1979; Atlas Tatrzańskiego Parku Narodowego, 1985).

Obydwie serie zostały przemieszczone z południa na obszar Tatr, seria wierchowa na odległości 5-15 km natomiast seria reglowa w granicach 50-100 km (Felisiak, 2008).

Dolina Pięciu Stawów Polskich w całości położona jest w obrębie granitoidowego trzonu krystalicznego Tatr Wysokich. Granitoidy te mają zróżnicowany skład petrograficzny - granity jądra krystalicznego, granity zautometamorfizowa- 


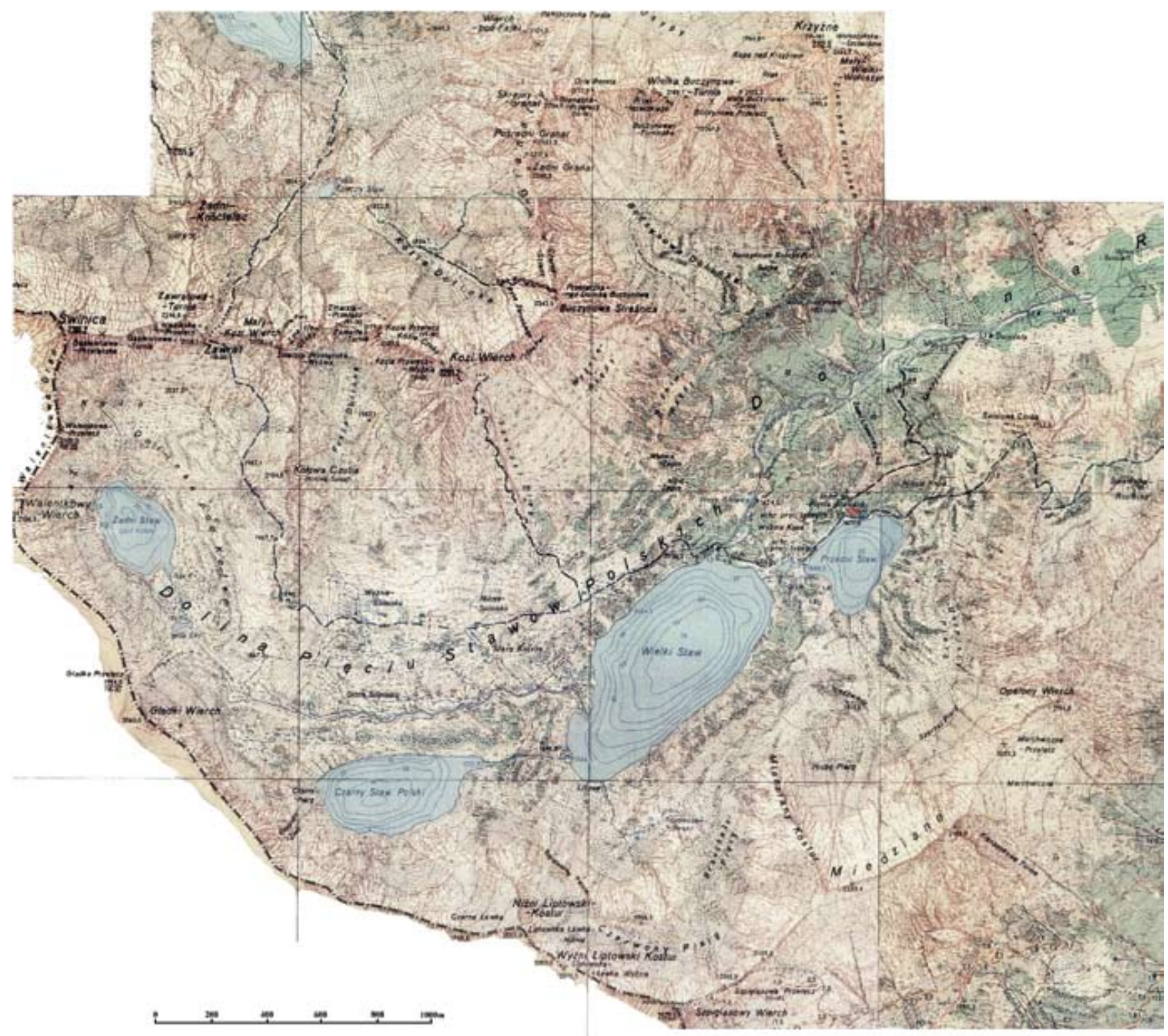

Fig. 1. Mapa topograficzna Doliny Pięciu Stawów Polskich (Atlas Tatrzańskiego Parku Narodowego (red. Trafas), 1985-częściowo zmienione) • Topographic map of the Five Ponds Valley after (Trafas, 1985, modified)

ne, granity brzeżnej strefy pegmatytowo-aplitowej. W ciągu grani od Świnicy do Koziego Wierchu, następnie od Wodospadu Siklawa wzdłuż szlaku aż do Przełęczy Krzyżne oraz w obrębie masywów Miedzianego i Opalonego znajdują się główne strefy występowania pegmatytów i aplitów (Michalik, 1951; Mapa Geologiczna Tatr Polskich, 1979).

Na obszarze Doliny Pięciu Stawów Polskich występują także mylonity, skały powstające w wyniku metamorfizmu dyslokacyjnego, którego głównym czynnikiem jest ciśnienie kierunkowe uwarunkowane naciskami tektonicznymi głównie w strefach uskokowych. Najliczniej spotykane są na Szpiglasowej Przełęczy, Szpiglasowym Wierchu, na Gładkiej Przełęczy, a także w grani „Orlej Perci”. Mylonity są skałami mało odpornymi na erozję, wynikiem czego, w strefach ich występowania, rozwinęły się przełęcze. Skały te są bardzo charakterystyczne, barwy szarej lub zielonkawej, złożone z drobnych pokruszonych i roztartych ziaren skał starszych i dobrze widoczne dla turystów poruszających się po szlaku. Na obszarze
Doliny Pięciu Stawów Polskich nie występują utwory permo- mezozoiczne ani trzeciorzędowe, natomiast większość dna doliny jest wypełniona utworami czwartorzędowymi pochodzenia polodowcowego (Mapa Geologiczna Tatr Polskich, 1979; Atlas Tatrzańskiego Parku Narodowego, 1985).

\section{Lodowce}

Prekursorem teorii dotyczącej występowania lodowców w Tatrach był krakowski geolog L. Zejszner. Udowodnił ją ostatecznie w roku 1856. Pomimo że od tego wydarzenia minęło ponad półtora wieku i wielu badaczy zajmowało się tą tematyką, ostateczna wersja, co do ilości i charakteru lodowców, nie jest ostatecznie ustalona. Dotychczasowe badania wskazują, że w Tatrach miało miejsce od trzech do pięciu okresów glacjalnych, które odpowiadały alpejskim zlodowaceniom günz-würm (w polskiej nomenklaturze narwiwisły) (Gądek, 1998). 
Najważniejszym zlodowaceniem, z punktu widzenia ukształtowania rzeźby terenu w Tatrach, było ostatnie zlodowacenie - würm, ponieważ rzeźba, którą po sobie pozostawiły wcześniejsze zlodowacenia, została przez nie zatarta lub przemodelowana.

Według przeprowadzonych przez Gądka (1998) rekonstrukcji, lodowiec glacjału würm w Dolinie Pięciu Stawów Polskich był lodowcem politermalnym. Osiągnął prawdopodobnie długość $2790 \mathrm{~m}$, a jego powierzchnia wynosiła $2,4 \mathrm{~km}^{2}$. Najwyższa część tego lodowca znajdowała się na wysokości 2140 m n.p.m. a najniższa 1690 m n.p.m. (rozciągłość wertykalna $450 \mathrm{~m}$ ). Średnia miąższość lodowca liczyła $105 \mathrm{~m}$, natomiast maksymalną grubość $160 \mathrm{~m}$ osiągnął w rejonie Zadniego Stawu. Lodowiec Doliny Pięciu Stawów Polskich był aktywnym polem firnowym zasilającym lodowiec Doliny Roztoki, który należał do większego lodowca - Doliny Białki.

W związku z ocieplaniem się klimatu pod koniec würmu lodowce w Tatrach zaczęły się wycofywać. Rozpoczęcie I fazy deglacjacji Doliny Pięciu Stawów Polskich nastąpiło prawdopodobnie 13000 lat temu, natomiast całkowity zanik lodowców w dolinie datowany jest na około 9000 lat temu.

Według Dzierżek, Lindner i Nitychoruk (1987) deglacjacja Doliny Pięciu Stawów Polskich przebiegała w czterech etapach, które w terenie wyznaczają kolejne wały moren czołowych, znajdujące się na progu zamykającym Dolinę Pięciu Stawów Polskich (etap I), w okolicy rygla Czarnego Stawu (etap II), następnie u wylotów Pustej Dolinki i Dolinki pod Kołem (etap III) oraz w górnych częściach kotłów Pustej Dolinki i Dolinki pod Kołem (etap IV). Etapy deglacjacji i za- sięgi lodowców przedstawiają figury $2-5$. W trzecim i czwartym etapie deglacjacji lodowce przekształciły się w lodowce gruzowe (Dobiński, 1994).

\section{Formy polodowcowe}

Po ustąpieniu lodowca odsłonił się szereg form powstałych zarówno w wyniku erozyjnej jak i akumulacyjnej działalności lodowca. Do niewątpliwe największych i najbardziej czytelnych w terenie należą kotły polodowcowe.

Kocioł polodowcowy, inaczej kar lub cyrk lodowcowy, wykształcony jest w postaci półkolistego lub owalnego zagłębienia otoczonego z trzech stron stromymi stokami lub ścianami skalnymi. Zwykle zamknięty jest on z czwartej strony ryglem skalnym lub moreną. Dno kotła lodowcowego może być nachylone, płaskie lub mieć charakter schodowy. Kocioł lodowcowy powstaje powyżej granicy wiecznego śniegu i jest efektem erozyjnej działalności lodowca górskiego.

W Dolinie Pięciu Stawów Polskich znajduje się aż sześć kotłów polodowcowych oraz jeszcze jeden - z Buczynowej Dolinki znajdujący się w jej bezpośrednim sąsiedztwie. Formy te szczegółowo opisał i scharakteryzował m.in. Klimaszewski (1988).

Kocioł Pustej Dolinki (Fig. 1 i 6) wycięty w południowych stokach Koziego Wierchu ma długość 980 m i szerokość $500 \mathrm{~m}$. Pierwotnie w jego obrębie znajdowało się kilka wciosowych dolinek rzecznych, jednakże w wyniku oddziaływania lodowca zostały one przekształcone w jeden kocioł lodowcowy. Kocioł od północy i wschodu otoczony jest ścianami skalnymi porozcinanymi żlebami, u wylotów których

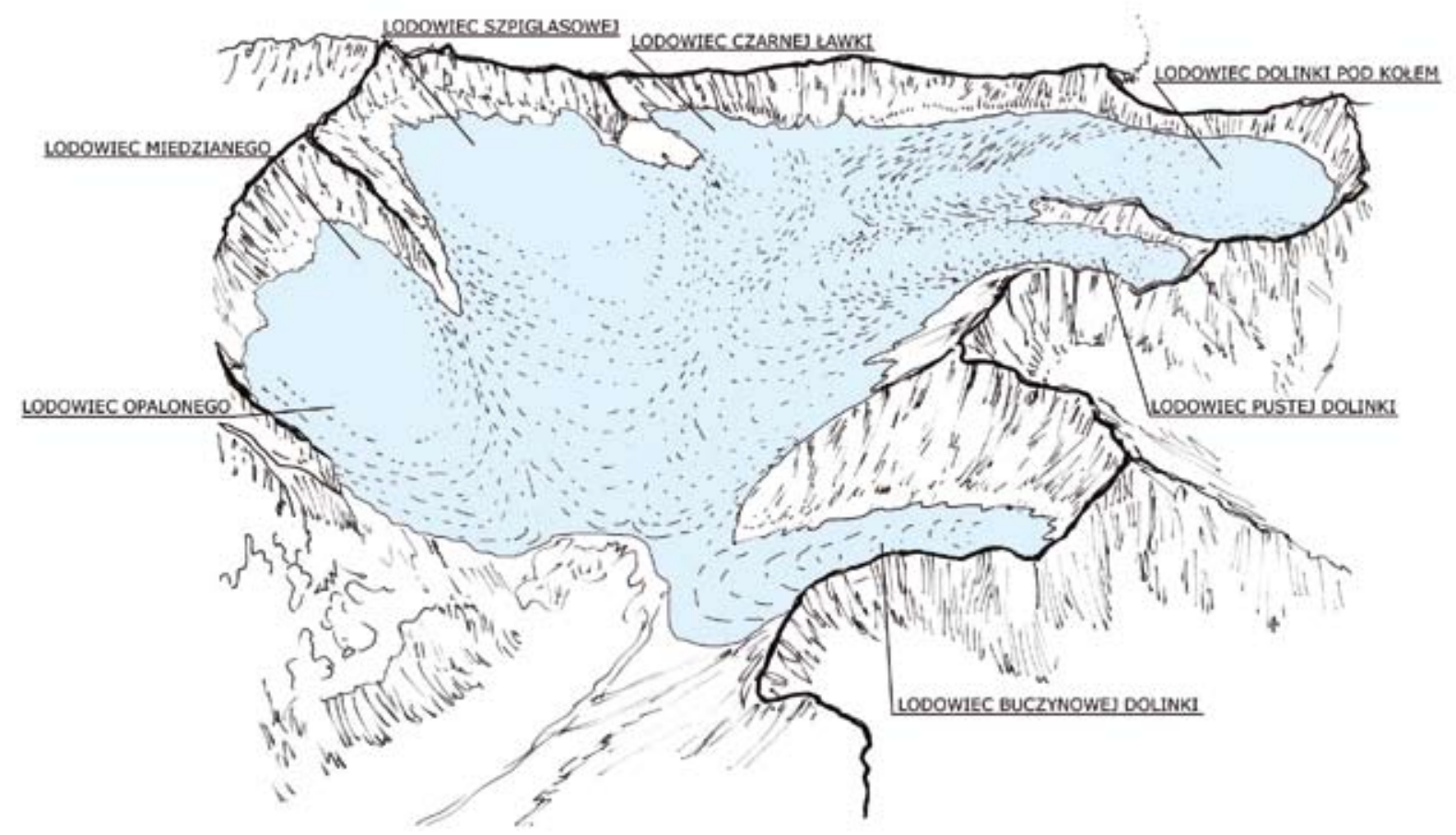

Fig. 2. Etap I - Cała Dolina Pięciu Stawów Polskich (Kotły: Opalonego, Miedzianego, Szpiglasowej, Czarnej Ławki, Dolinki pod Kołem i Pustej Dolinki) jak i kocioł Buczynowej Dolinki przykryte są lodem (Mrowczyk, Madeja, 2008; na podstawie: Dzierżek i in., 1987) - Stage I - The whole Five Ponds Valley (including cirques of Opalone, Miedziane, Szpiglasowa, Czarna Ławka peaks as well as pod Kołem and Pusta valleys) and the Buczynowa Valley cirque filled with glaciers (Mrowczyk, Madeja, 2008; after Dzierżek 1987) 


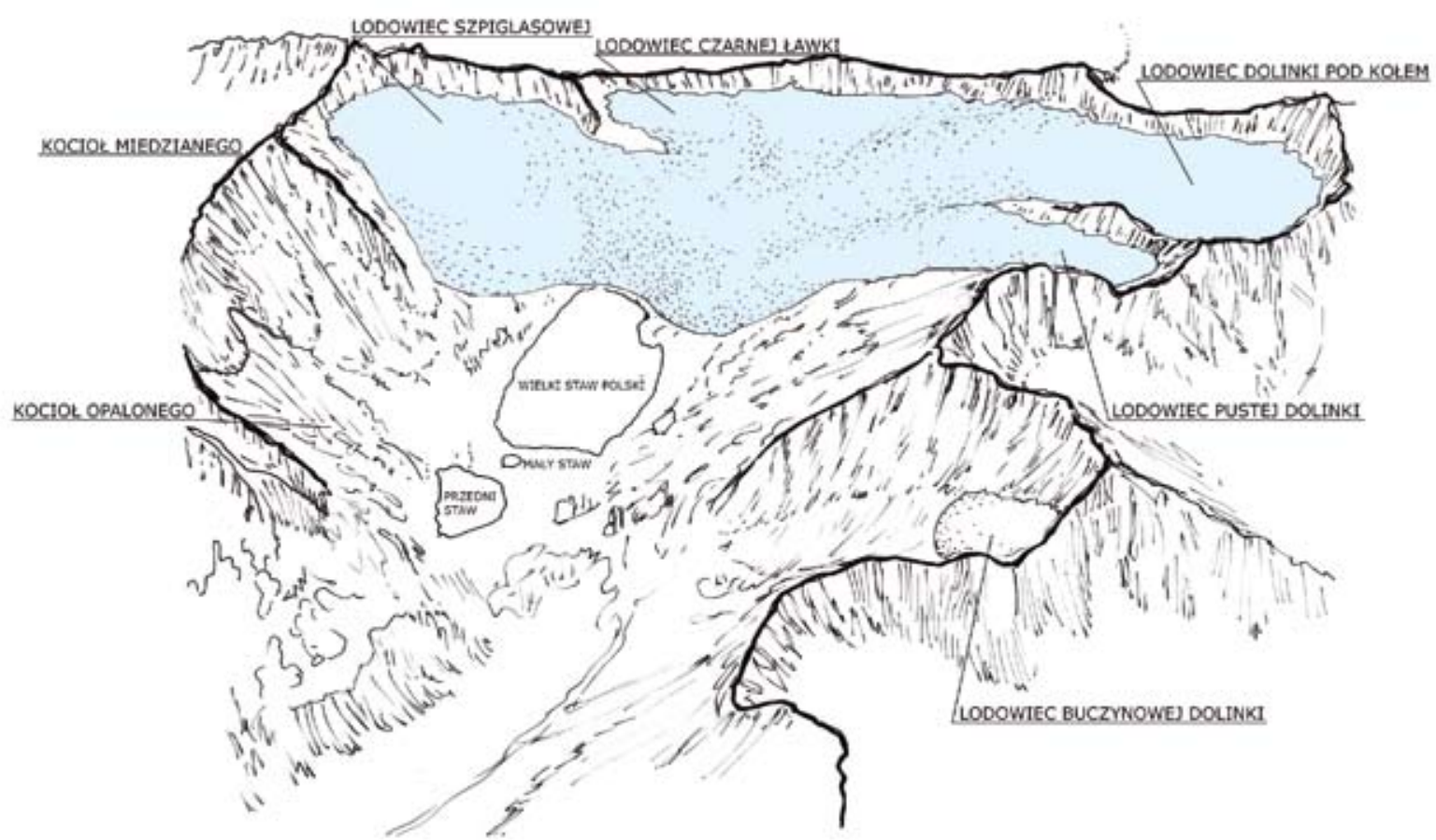

Fig. 3. Etap II - Lodowiec sięga do okolic rygla Czarnego Stawu (zajmując kotły: Szpiglasowej, Czarnej Ławki, Dolinki pod Kołem i Pustej Dolinki), natomiast kocioł Buczynowej Dolinki zajęty jest jedynie w górnej części (Mrowczyk, Madeja, 2008; na podstawie: Dzierżek i in., 1987) - Stage II - Glacier descends towards the vicinity of the Czarny Pond riegel covering the cirques of Szpiglasowa, Czarna Ławka, Pod Kołem and Pusta valleys whereas the Buczynowa Valley cirque is glaciated only in its upper part (Mrowczyk, Madeja, 2008; after Dzierżek et al., 1987)

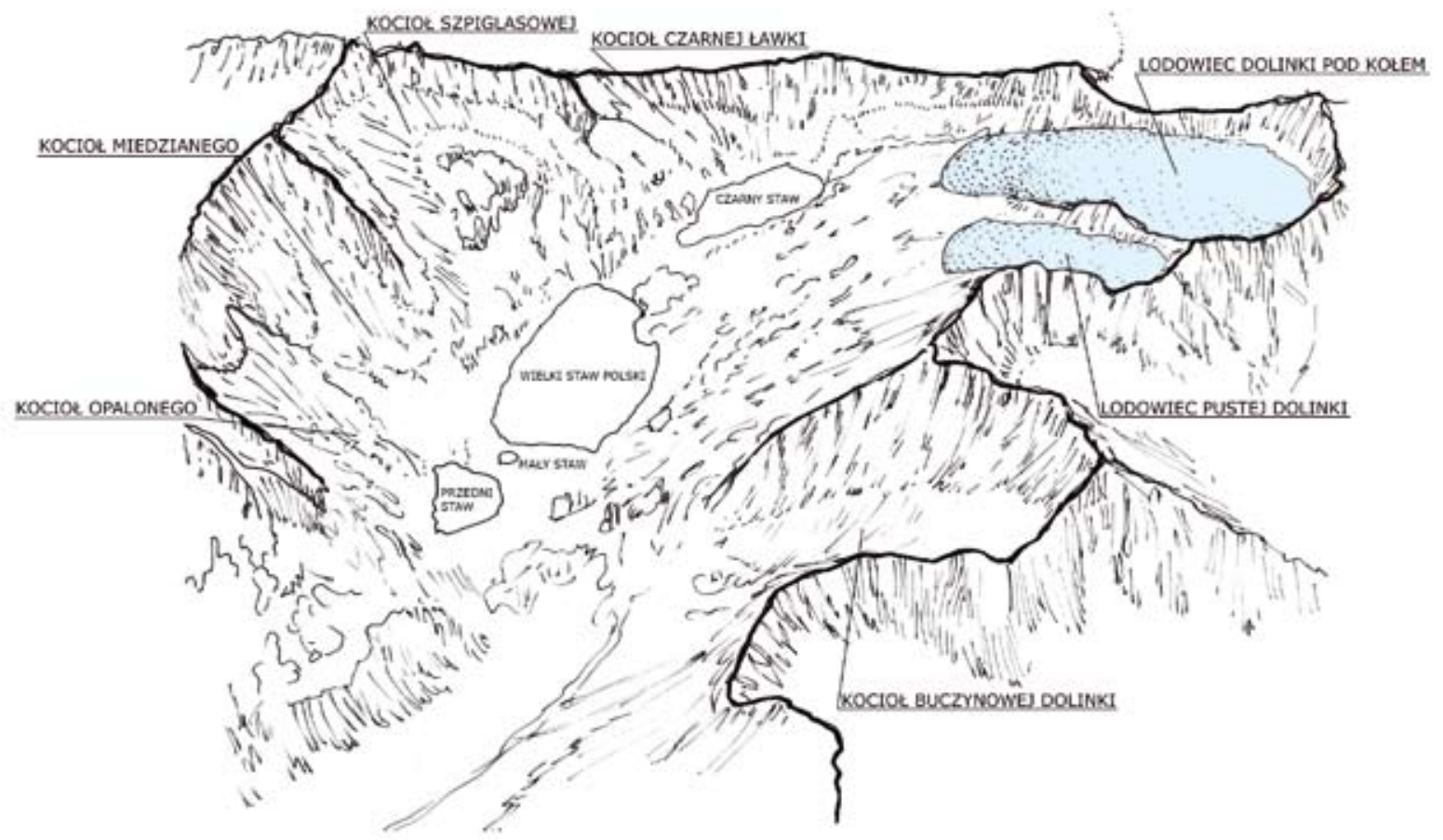

Fig. 4. Etap III - Lodowce przekształcają się w lodowce gruzowe i zajmują już tylko kocioł Dolinki Pustej i kocioł Dolinki pod Kołem (Mrowczyk, Madeja, 2008; na podstawie: Dzierżek i in., 1987) • Stage III - glaciers evolve into rock glaciers and occupy only the Pusta and Pod Kołem valleys cirques (Mrowczyk, Madeja, 2008; after Dzierżek et al., 1987) 


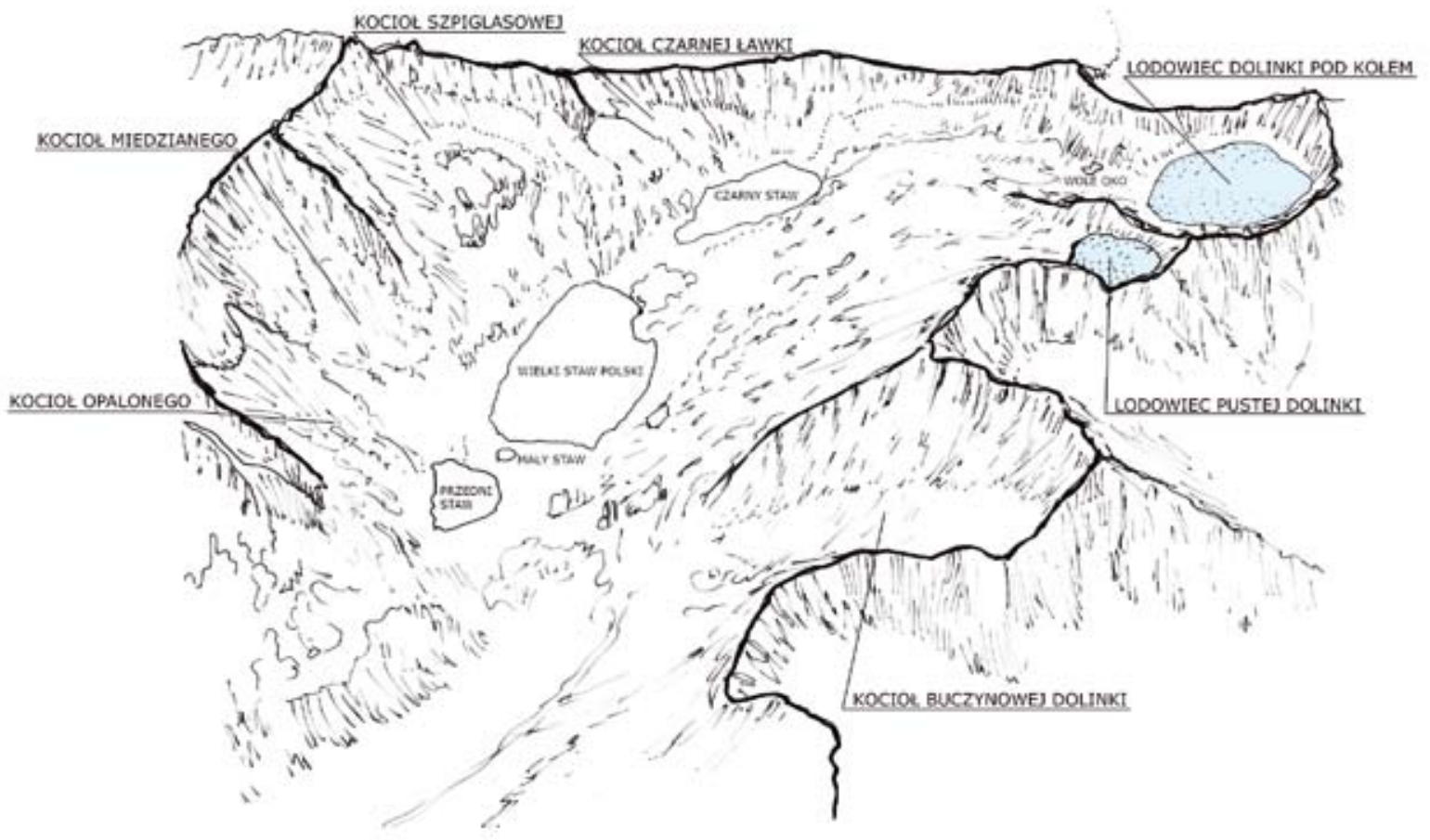

Fig. 5. Etap IV - Lodowce gruzowe zajmują jedynie wysoko położony kocioł Pustej Dolinki i kocioł Dolinki pod Kołem (Mrowczyk, Madeja, 2008; na podstawie: Dzierżek i in., 1987) - Stage IV - rock glaciers occupy only the high-terrain Pusta and Pod Kołem valleys cirques (Mrowczyk, Madeja, 2008; after Dzierżek et al., 1987)

znajdują się piarżyska o nachyleniu do $35^{\circ}$ oraz zwały obrywów. Od strony zachodniej kocioł oddzielony jest grzbietem Kołowej Czuby od kotła Dolinki pod Kołem. Dno kotła jest dwustopniowe. Dno górne położone na wysokości 19401985 m n.p.m. zamknięte podwójnym wałem moreny czołowej, opada $50 \mathrm{~m}$ wysokości progiem w kierunku niższego, znajdującego się na wysokości 1880-1850 m n.p.m. Dno dolne opada także $50 \mathrm{~m}$ progiem w kierunku doliny głównej. Dolinka zamknięta jest wałem morenowym, rozmytym w części centralnej (Klimaszewski, 1988).

Morena to forma ukształtowania powierzchni Ziemi w postaci wzniesienia, wału, wzgórza lub ciągu wzgórz, powstała w wyniku akumulacji materiału skalnego, zdeponowanego przez lodowiec. Materiał charakteryzuje się brakiem wysortowania i obecnością wszystkich frakcji od bloków przez żwiry, piaski, pyły i iły. Pochodzi on głównie z niszczonego przez lodowiec podłoża oraz ze zboczy doliny wznoszących się ponad lodowiec. Wyróżnia się kilka typów moren, z których najbardziej znane są morena denna i morena czołowa. Ta ostatnia tworzy się wzdłuż czoła lodowca w czasie stagnacji w okresie jego etapowego zaniku, tworząc formę często wyraźnie zaznaczającą się w terenie (Fig. 7). Zbudowana jest ona $\mathrm{z}$ gliny zwałowej, złożonej z materiału transportowanego wewnątrz i w stopie lodowca oraz na jego powierzchni. Jest to rodzaj gliny zbudowanej $z$ materiału ilastego $\mathrm{z}$ domieszką frakcji grubszych tworzącej niewarstwowaną skałę osadową.

Dolinka pod Kolem (Fig. 1 i 6), będąca obszernym kotłem polodowcowym, jest najdłuższą dolinką w obrębie Doliny
Pięciu Stawów Polskich. Jej długość wynosi 1350 m, jednakże szerokość zaledwie $350 \mathrm{~m}$. Jest ona wycięta w południowych stokach masywu Świnicy i Małego Koziego Wierchu. Strome ściany w dużej części są porozcinane żlebami, u wylotów których znajdują się stożki piargowe. Początek Dolinki pod Kołem stanowi nisza znajdująca się w ścianie Świnicy na wysokości 2050 do 2150 m n.p.m, która okryta jest stożkami piargowymi. Nisza ta opada $50 \mathrm{~m}$ progiem skalnym w kierunku nierównego, przegłębionego dna doliny, przeobrażonej w kocioł lodowcowy. Dno kotła jest dwupoziomowe. Poziom wyższy znajduje się na wysokości od 1990 do 1950 m n.p.m. w obrębie północnego obrzeżenia misy Zadniego Stawu. Niższy, zasadniczy poziom dna obniża się do wysokości 1900-1850 m n.p.m.. W tym poziomie wycięta jest misa Zadniego Stawu, której powierzchnia wynosi 6,5 ha a głębokość $31 \mathrm{~m}$ (Klimaszewski, 1988).

Podczas ostatnich faz wycofywania się lodowca Doliny Pięciu Stawów Polskich (III,IV), w obrębie Dolinki pod Kołem oraz Dolinki Pustej występowały lodowce gruzowe, które pozostawiły po sobie charakterystyczne osady. Sa to pokrywy gruzowe bardzo dobrze widoczne w terenie, których materiał jest niewysortowany i ostrokrawędzisty, a rozmiary pojedynczych bloków mogą osiągać wielkość powyżej $1 \mathrm{~m}^{3}$ (Dobiński, 1994; Dzierżek i in., 1987).

Kociol Czarnej Lawki (Fig. 1 i 8) ograniczony jest granią Czarnej Ławki i Niżnego Kostura, ma długość 450 m i jest wykształcony w postaci dwustopniowej, pochyłodennej niszy o przeważnie gładkich zboczach okrytych rumowiskiem. Dno wyższe wykształcone jest jako spłaszczenie znajdujące się 


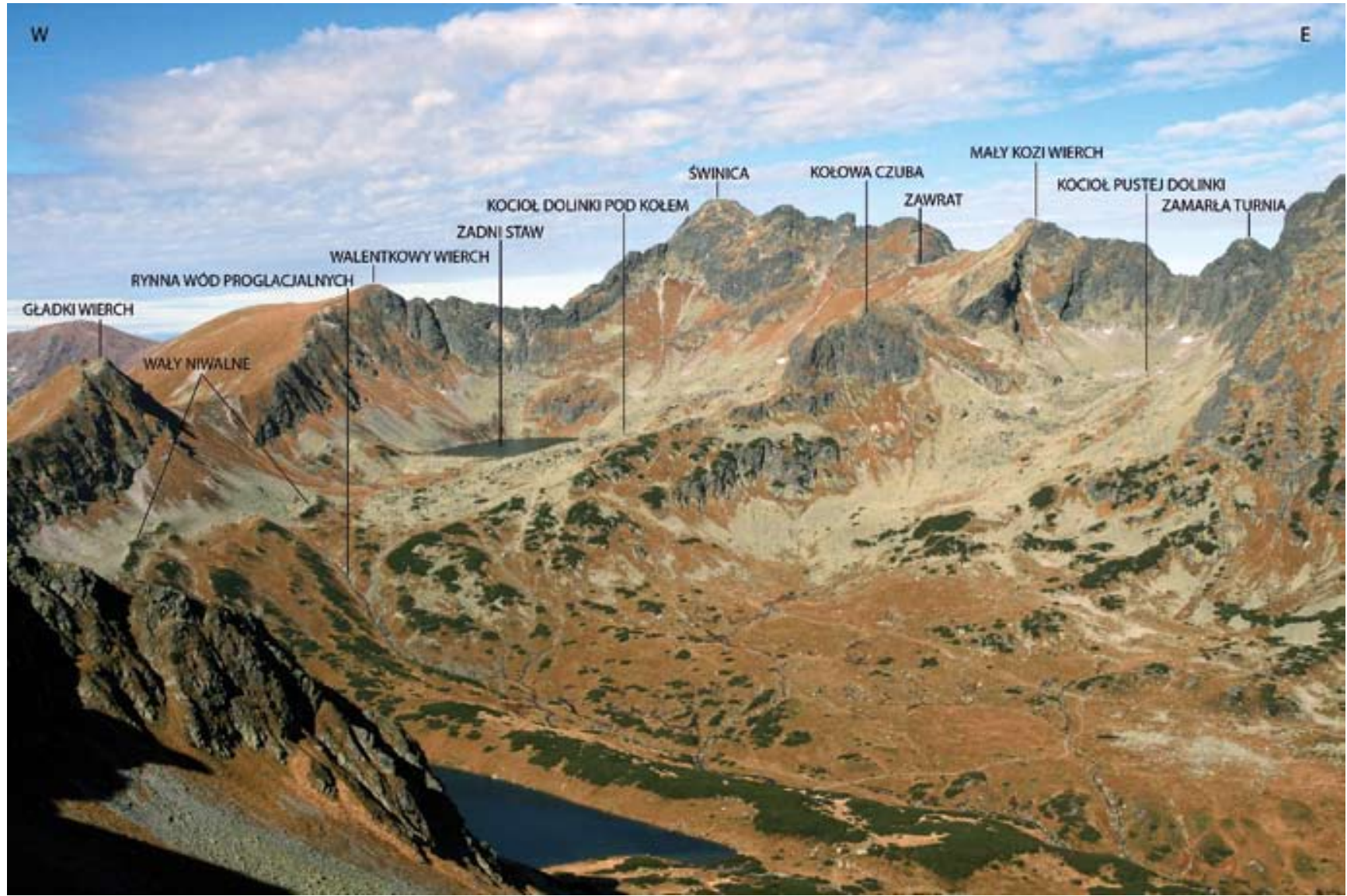

Fig. 6. Zachodnia część Doliny Pięciu Stawów Polskich widziana z żółtego szlaku z okolicy Szpiglasowej Przełęczy (fot. Madeja) • Western part of the Five Ponds Valley, view from the yellow trail near the Szpiglasowa Pass (phot. Madeja)

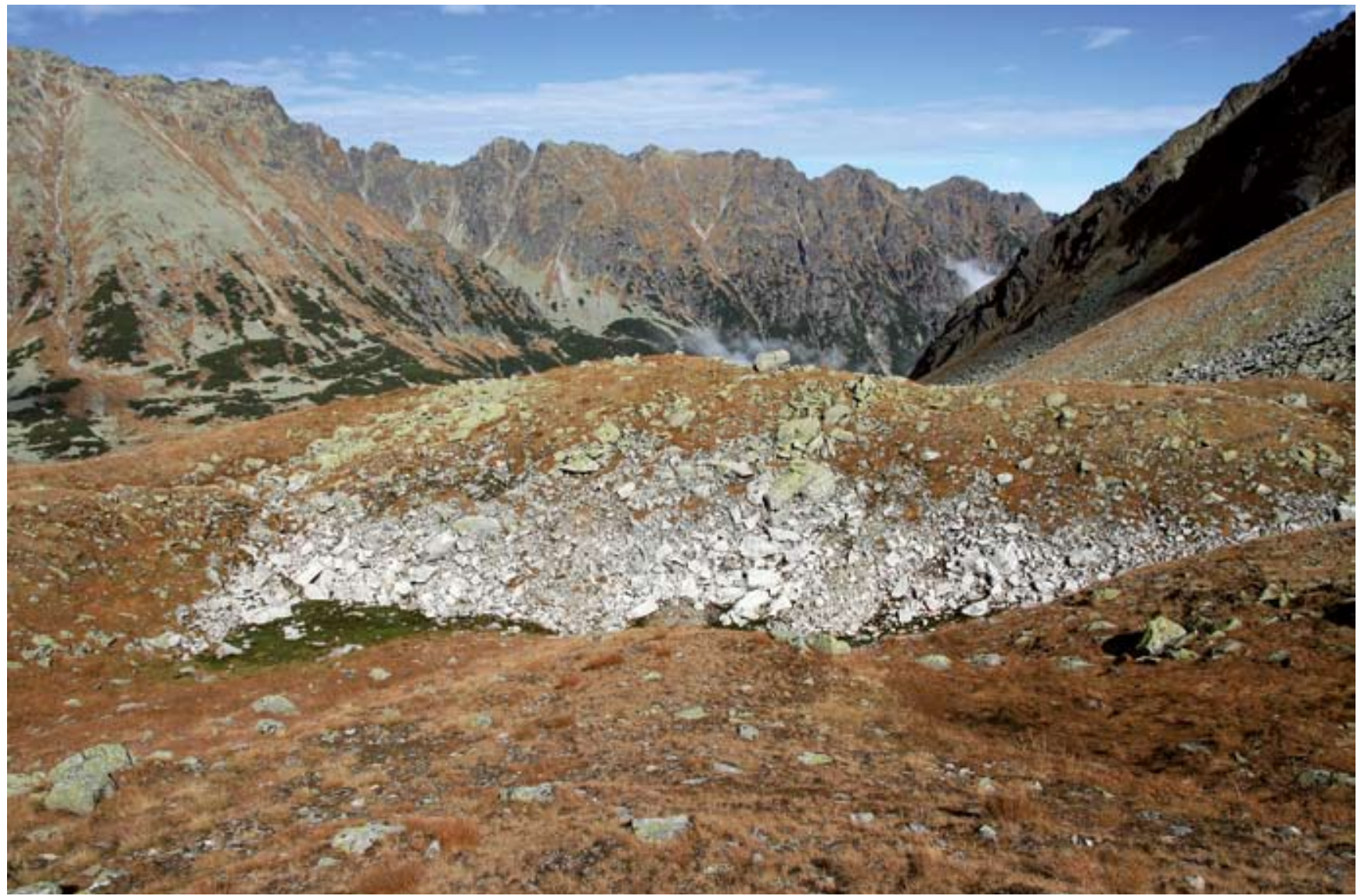

Fig. 7. Wał moreny czołowej widoczny w Kotle Szpiglasowej (fot. Madeja) • Terminal moraine in the Szpiglasowa cirque (phot. Madeja) 


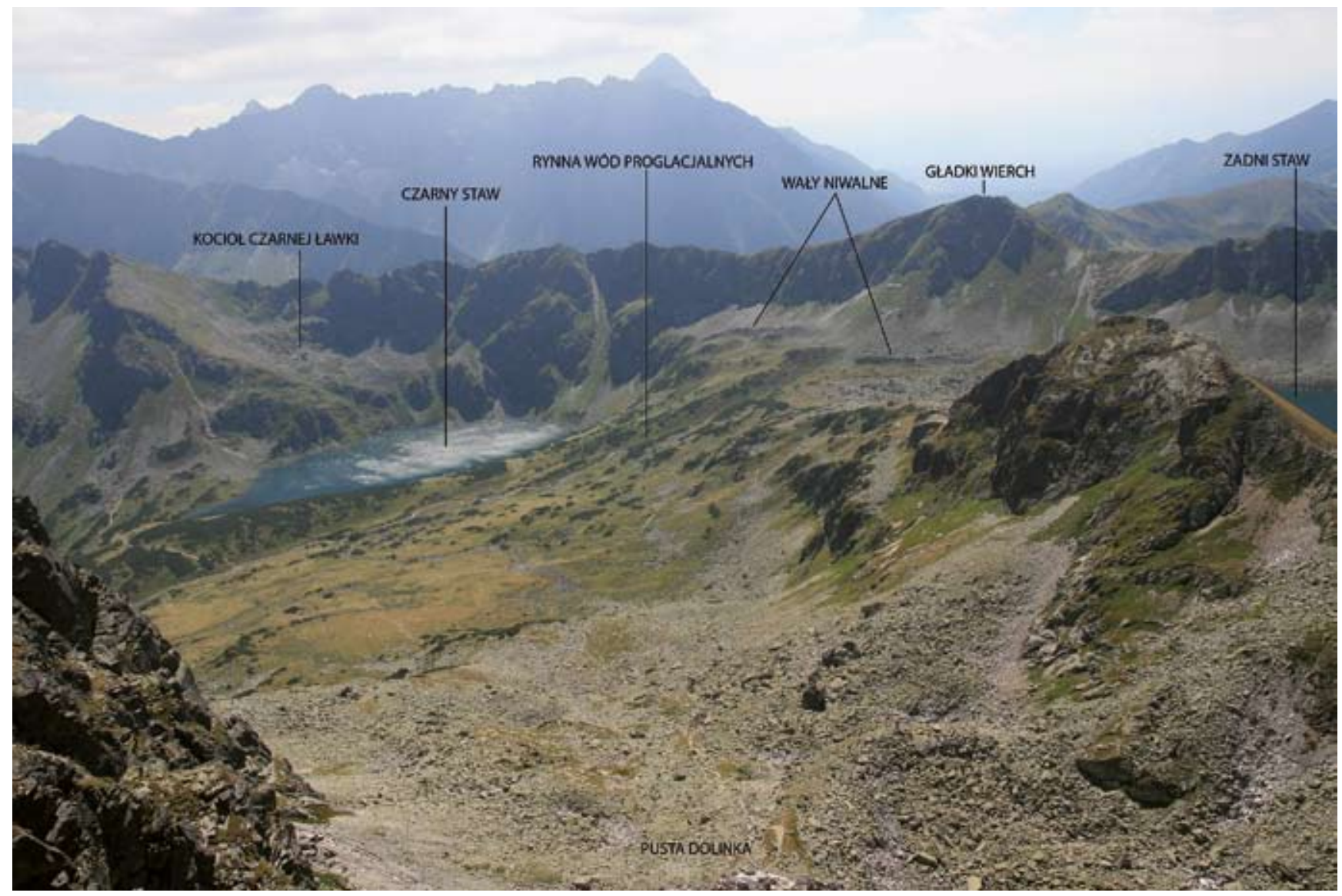

Fig. 8. Centralna część Doliny Pięciu Stawów Polskich widziana z okolicy Koziej Przełęczy Wyżniej (fot. Mrowczyk) • Central part of the Five Ponds Valley, view from the Kozia Przełęcz Wyżna Pass (phot. Mrowczyk).

na wysokości 1900-1880 m n.p.m. i opada skalistym progiem w kierunku dna niższego, znajdującego się na wysokości 1830-1790 m n.p.m. To ostatnie z kolei opada skalistym progiem ku rynnie Czarnego Stawu, a w dolnej części okryte jest piargiem (Klimaszewski, 1988).

Kociol Szpiglasowej (Fig. 1 i 9) jest to charakterystyczny polodowcowy kocioł piętrowy o długości $800 \mathrm{~m}$ i podobnej szerokości. Jest on ograniczony granią Niżnego Kostura, Liptowskich Murów oraz ramieniem Szpiglasowego Wierchu. Kocioł powstał w wyniku przeobrażenia kilku dolinek preglacjalnych przez masy firnowo-lodowe. Na Kocioł Szpiglasowej składają się trzy półkoliste kotły położone jeden nad drugim, które kolejno opadają do siebie. Cechą charakterystyczną jest fakt, iż kotły niższe rozrastały się kosztem wyższych. Kocioł górny posiada nierówne dno na wysokości 1980-1920 m n. p.m. W obrębie tego kotła znajdują się dwa wały morenowe: starszy - zewnętrzny o długości $600 \mathrm{~m}$ i wysokości 6-8 m oraz młodszy - wewnętrzny o wysokości ok. $15 \mathrm{~m}$. Dno kolejnego kotła - środkowego, położone jest na wysokości 1780-1750 m n.p.m. i w jego obrębie występują niewielkich rozmiarów mutony. Z kolei najniżej położony kocioł dolny jest słabo wykształcony i najmniej widoczny. Jego dno znajduje się na wysokości 1700 m n.p.m., jest spłaszczone, wygładzone i zasypane rumowiskiem (Klimaszewski, 1988).

Kocioł Miedzianego (Fig. 1 i 9) jest wycięty w północnych stokach Miedzianego, a ograniczają go skalne ściany roz- członkowane przez urwiste żleby. Jego wymiary to $700 \mathrm{~m}$ długości i $350 \mathrm{~m}$ szerokości. U wylotu żlebu centralnego znajduje się olbrzymi stożek Hrubego Piargu o wysokości $250 \mathrm{~m}$ i długości $450 \mathrm{~m}$. Na wysokości 1800 m n.p.m. znajduje się dno kotła, które od strony północnej zamknięte jest wałem morenowym o wysokości 5-8 m (Klimaszewski, 1988).

Kocioł Opalonego (Fig. 1 i 9) jest wycięty w północnozachodnich zboczach Miedzianego i Opalonego Wierchu, jego długość oraz szerokość są zbliżonych rozmiarów i wynoszą około $450 \mathrm{~m}$. Tak szeroki kocioł powstał w wyniku połączenia dwóch dolinek fluwialnych: spod szczytu Miedzianego oraz spod Przełęczy Marchwicznej. Kocioł otoczony jest ścianami skalnymi gęsto porozcinanymi żlebami. Dno znajduje się na wysokości 1740-1780 m n.p.m. jest zadarnione, zamknięte jest natomiast przez półkolisty wał moreny czołowej o wysokości 10-20 m (Klimaszewski, 1988).

Dolinka Buczynowa (Fig. 1 i 10), znajdująca się w bezpośrednim sąsiedztwie Doliny Pięciu Stawów Polskich jest przykładem najbardziej typowych kotłów lodowcowych na terenie Tatr, a zarazem jest typowym przykładem wiszącej dolinki. Jej długość wynosi $950 \mathrm{~m}$ a szerokość $400 \mathrm{~m}$. Dolinka jest otoczona urwistymi skalnymi ścianami Koziego Wierchu, Granatów, Orlej Baszty i Wielkiej Buczynowej, które są silnie poprzecinane żlebami, u których wylotów znajdują się olbrzymie, przeważnie czynne, stożki piargowe 


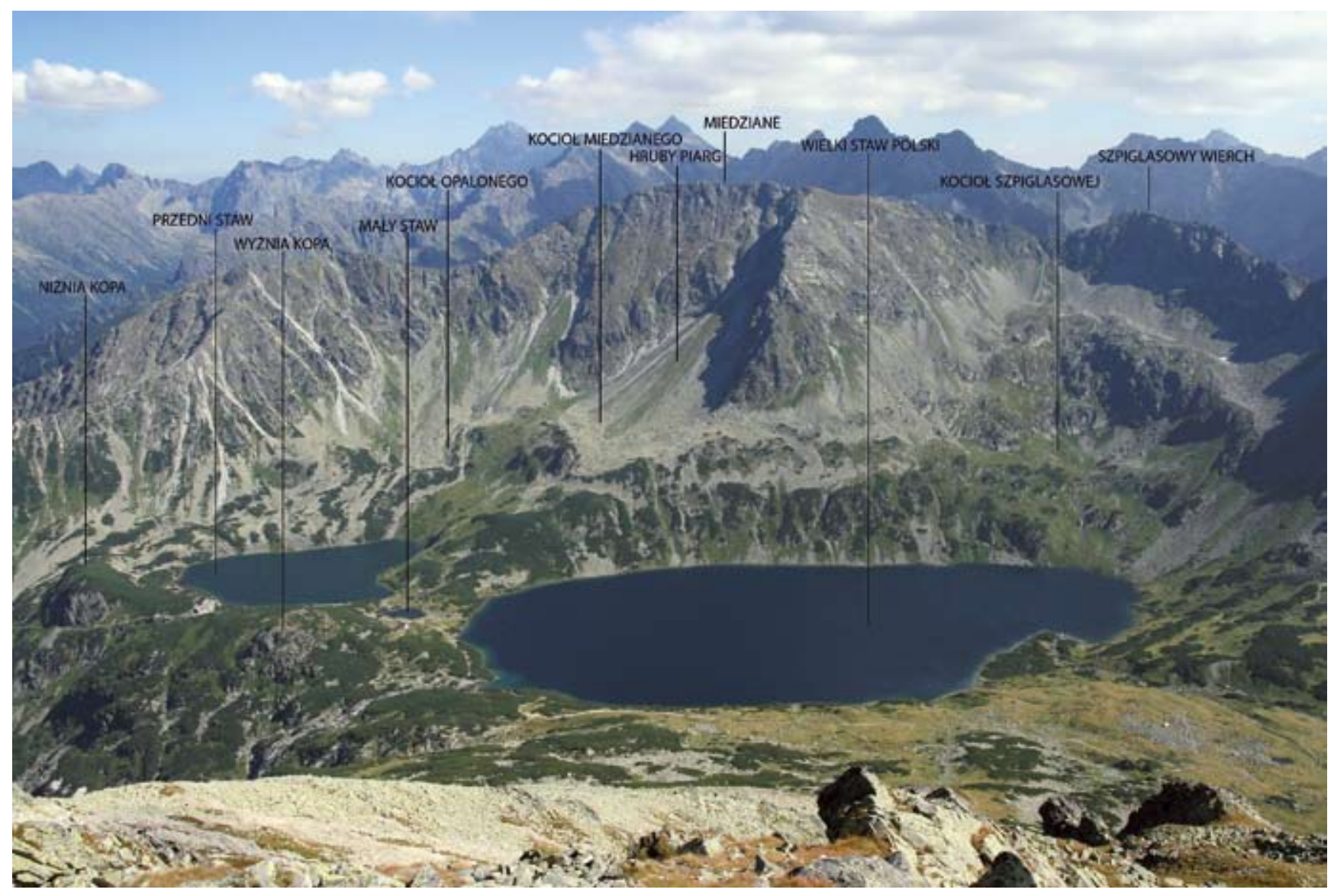

Fig. 9. Wschodnia część Doliny Pięciu Stawów Polskich widziana z żółtego szlaku z Koziego Wierchu (fot. Mrowczyk) • Eastern part of the Five Ponds Valley, view from the yellow trail at the Kozi Wierch peak (phot. Mrowczyk)

o maksymalnej wysokości $200 \mathrm{~m}$. Sam kocioł jest dwustopniowy i powstał $\mathrm{w}$ wyniku przeobrażenia przez lodowiec kilku wciosowych dolinek rzecznych. Górne dno kotła jest wklęsłe i znajduje się na wysokości 1790-1800 m n.p.m. Zagłębienie zamknięte jest przez podwójny wał moreny czołowej: wewnętrzny o wysokości do $30 \mathrm{~m}$, zewnętrzny o wysokości 5-10 m. Dno górne opada progiem w kierunku dna dolnego położonego na wysokości 1695-1740 m n.p.m. Dno poziomu dolnego jest nierówne i pogarbione. Dolinka jest zamknięta wałem moreny czołowej o wysokości około 10 m. Kocioł Buczynowej Dolinki opada bezpośrednio do Doliny Roztoki wysokim na 260 m skalnym progiem. Próg ten w górnej części jest dobrze ogładzony, natomiast niżej poszarpany i urwiskowy. Ponadto próg rozcięty jest sześcioma gardzielami o stromych ścianach, których głębokość nie przekracza $20 \mathrm{~m}$. Łączą się one w trzy rynny wycięte przez wody proglacjalne lodowca, z których dwie odprowadzaja wody z Dolinki Buczynowej (Klimaszewski, 1988).

W Dolinie Pięciu Stawów Polskich występuje sześć głównych zbiorników wodnych, z których pięć wypełnia misy bądź niecki polodowcowe. Jedynie Wole Oko jest jeziorkiem niewystępującym w głębokiej formie polodowcowej. (Klimaszewski, 1988)

Misa Zadniego Stawu (Fig. 1 i 6) jest ograniczona stromymi, skalistymi brzegami, które wznoszą się $15 \mathrm{~m}$ ponad poziom wody Zadniego Stawu, w związku z czym całkowi- ta głębokość misy wynosi $40 \mathrm{~m}$. Od strony południowej misa Zadniego Stawu zamknięta jest przez rygiel skalny, na którym znajduje się morena czołowa o wysokości od 6 do 15 m (Klimaszewski, 1988).

Niecka Wielkiego Stawu Polskiego (Fig. 1 i 9) ma długość $998 \mathrm{~m}$, szerokość $425 \mathrm{~m}$ i głębokość $79 \mathrm{~m}$. Powstanie jej związane jest z konfluencją mas lodowych, spływających z Dolinki pod Kołem, Dolinki Pustej, kotła Czarnej Ławki oraz kotła Szpiglasowej. Od północnego-wschodu staw otacza wał moreny czołowej o wysokości 8-25 m (Klimaszewski, 1988).

Misa Przedniego Stawu (Fig. 1 i 9) ma długość 396 m, szerokość 306 m i głębokość 35 m. Zagłębienie, w którym znajduje się staw, powstało w wyniku konfluencji jęzorów lodowcowych spływających z kotłów: Miedzianego oraz Opalonego. Misę tego stawu otacza $z$ trzech stron wał morenowy ciągnący się od Wielkiego Stawu Polskiego o wysokości od 8 do $25 \mathrm{~m}$. Zwierciadło wody położone jest na wysokości 1668 m n.p.m. Wody odprowadzane są okresowo do Wielkiego Stawu rynną, która przecina Mały Staw, w pozostałych przypadkach wody ,znikają" w utworach morenowych (Klimaszewski, 1988).

Mały Staw (Fig. 1 i 9) położony na wysokości $1668 \mathrm{~m}$ n.p.m. ma 68 m długości, 36 m szerokości oraz 2,1 m głębokości. Jest to staw pochodzenia wytopiskowego i występuje 


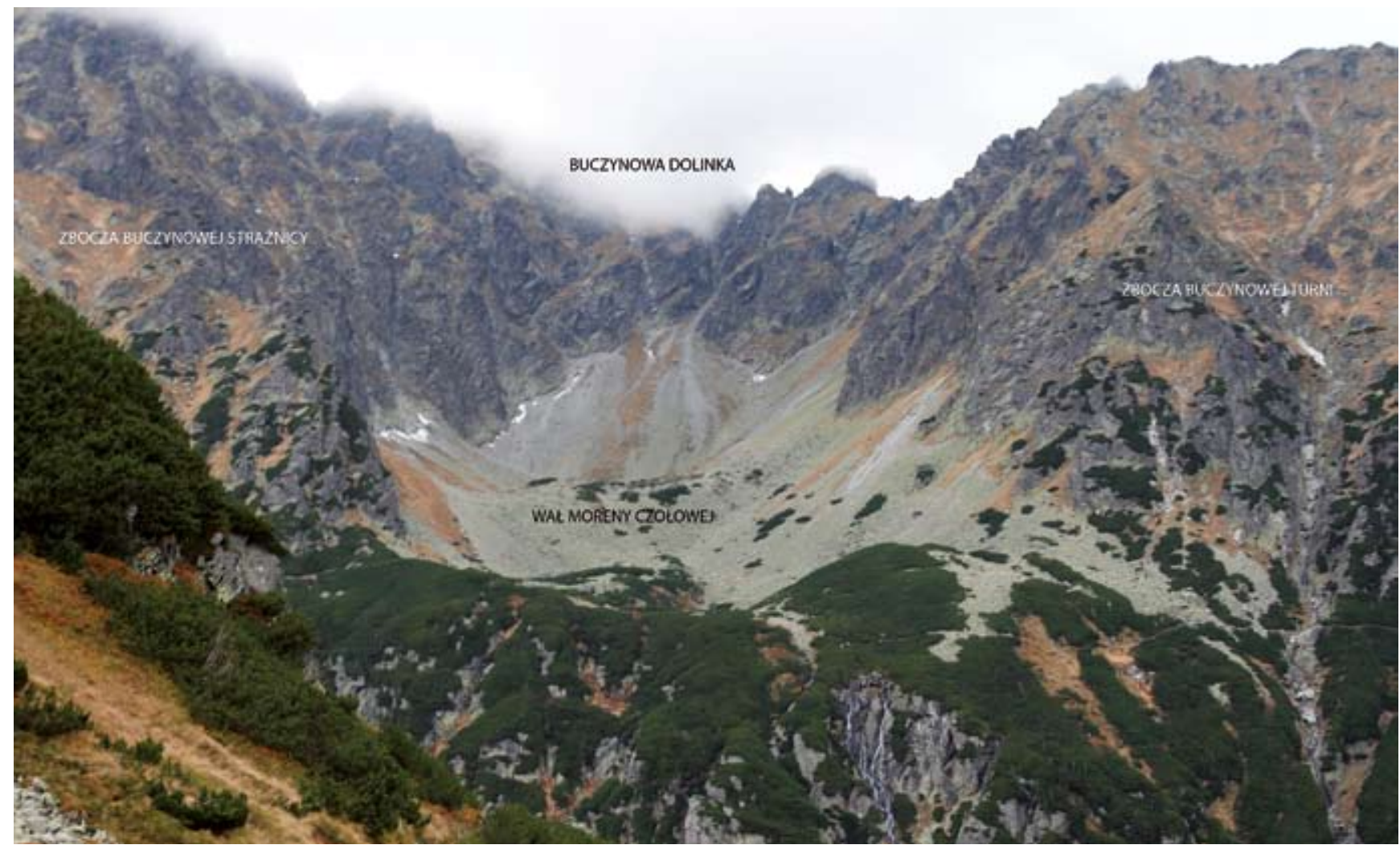

Fig. 10. Buczynowa Dolinka widziana z niebieskiego szlaku „przez świstówkę” (fot. Madeja) • Cirque of the Buczynowa Valley as a typical example of hanging valley (phot. Mrowczyk)

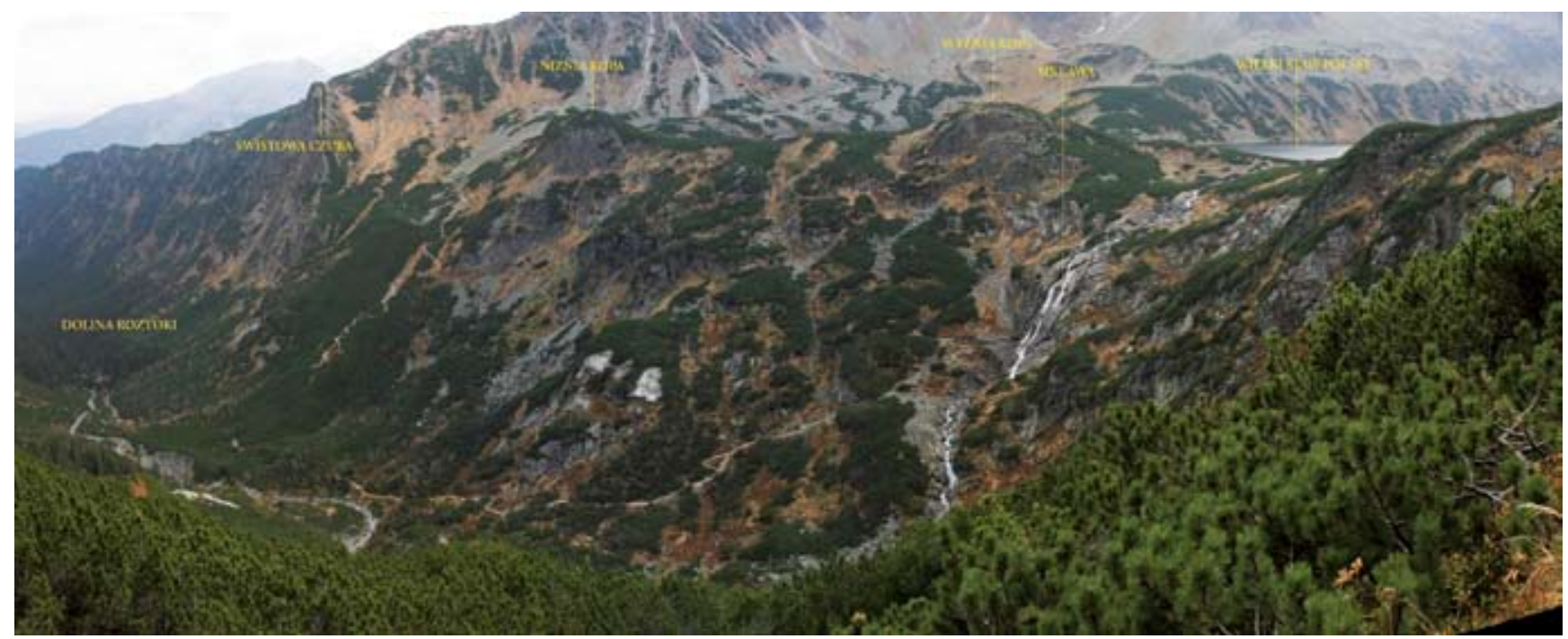

Fig. 11. Próg zamykający Dolinę Pięciu Stawów Polskich widziany z żółtego szlaku z okolicy Buczynowej Dolinki (fot. Mrowczyk) • Rock step terminating the Five Ponds Valley, view from the yellow trail in the vicinity of the Buczynowa Valley (phot. Mrowczyk)

w obrebie pomostu, który buduja utwory moreny dennej. Położony jest pomiędzy Wielkim Stawem Polskim i Przednim Stawem (Klimaszewski, 1988).

Niecka Czarnego Stawu (Fig. 1 i 8) powstała w wyniku konfluencji jęzorów lodowcowych spływających z Dolinki pod Kołem, Dolinki Pustej oraz z kotła Czarnej Ławki. Zwierciadło wody tego stawu znajduje się na wysokości $1665 \mathrm{~m} \mathrm{n}$. p.m.. W wyniku działalności lodowca, płynącego z Dolinki Pustej, dno w części południowej zostało mocno przegłębione, dodatkowo przegłębienie można tłumaczyć położeniem niecki zaraz u podnóża progu, w obrębie którego masy lodu prze- mieszczały się z większa prędkościa, a zarazem oddziaływały na podłoże z większą siłą (Klimaszewski, 1988).

Wole Oko jest małym jeziorkiem znajdującym się na przedpolu moreny czołowej Zadniego Stawu. Znajduje się ono w wydłużonym, głębokim na $15 \mathrm{~m}$, zagłębieniu o stromych, często skalistych zboczach. Wody doprowadzane do niego pochodzą $z$ Zadniego Stawu, a jego geneza nie jest do końca poznana (Klimaszewski, 1988).

Dolinę Pięciu Stawów Polskich zamyka rygiel skalny (Fig. 11), przebiegający skośnie do doliny i mierzący $1400 \mathrm{~m}$ długości (szerokość Doliny Pięciu Stawów Polskich wynosi 1000 m). 


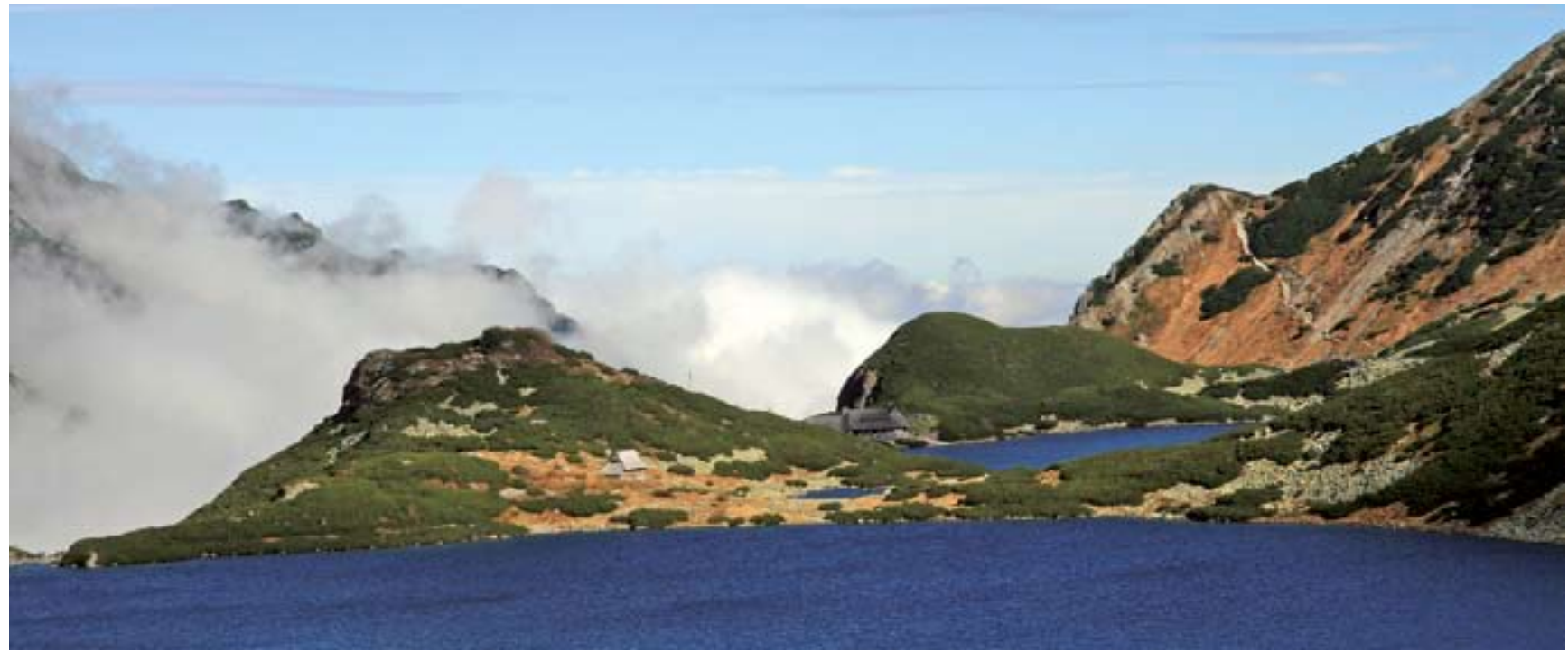

Fig. 12. Mutony: Wyżnia Kopa i Niżnia Kopa usytuowane przy Przednim Stawie (fot. Madeja) • The Wyżnia Kopa and Niżnia Kopa roches mountonnées located close to the Przedni Staw pond (phot. Madeja).

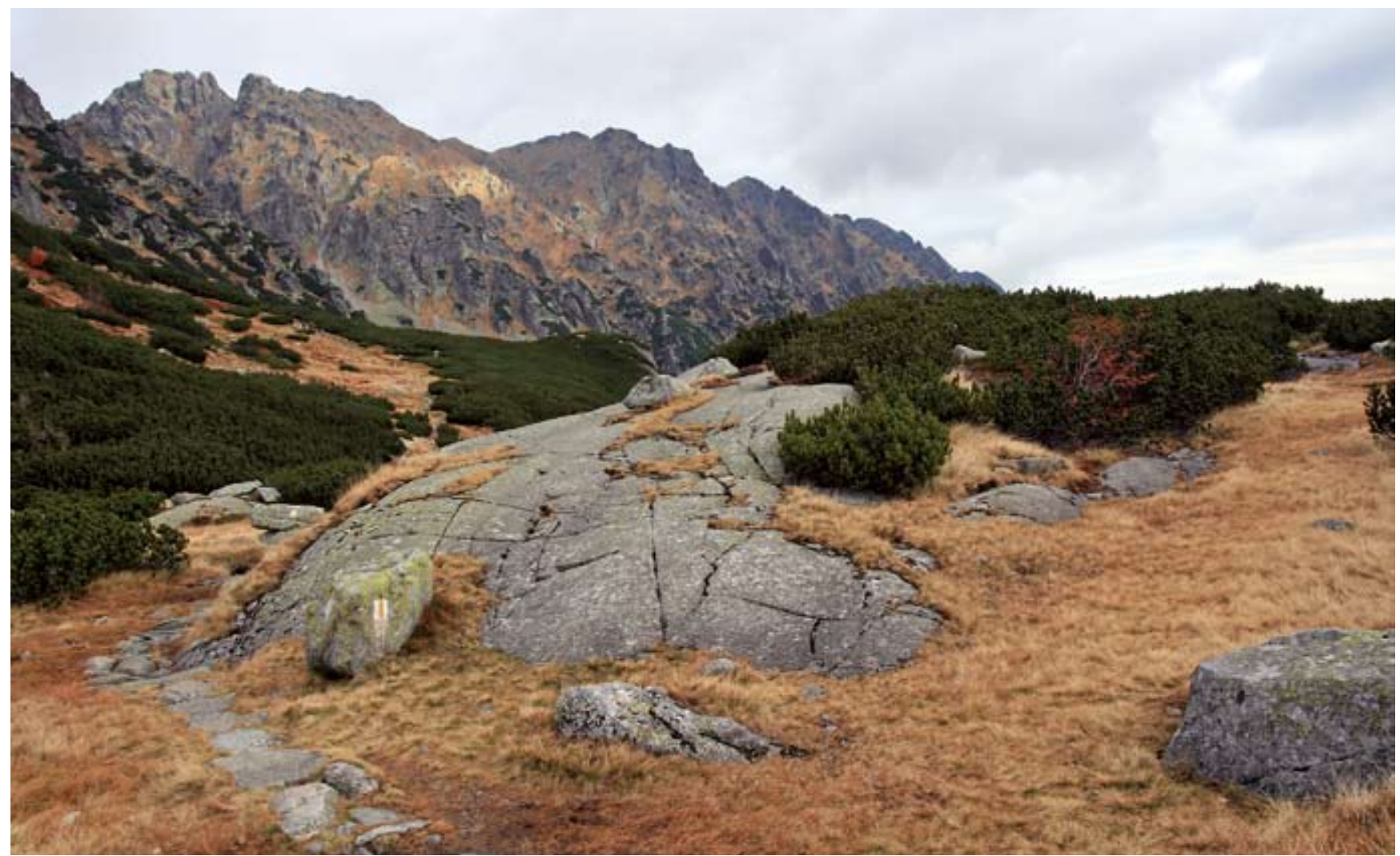

Fig. 13. Muton z bardzo dobrze zachowanym wygładem lodowcowym (fot. Mrowczyk) $\bullet$ Roche mountonée with very well-preserved polished surface (phot. Mrowczyk)

Rygiel skalny to wał litej skały zagradzający w poprzek U-kształtna dolinę polodowcową, w której może oddzielać np. cyrk lodowcowy od niższego odcinka doliny.

W ryglu zamykającym Dolinę Pięciu Stawów Polskich można wyróżnić dwa odcinki: S-E oraz N-W. Granicę między nimi wyznacza Wyżnia Kopa (1772 m n.p.m.). Zarówno Wyżnia Kopa jak i Niżnia Kopa (1711 m n.p.m.) są mutonami znacznych rozmiarów o bardzo dobrze odróżniających się stokach proksymalnych i dystalnych (Fig. 1, 11 i 12).

Muton, inaczej baraniec, to forma ukształtowania terenu na ogół w postaci skalistego pagórka o powierzchni zaokrą- glonej i wygładzonej przez lodowiec, wysokości od kilkunastu centymetrów do kilkudziesięciu metrów. Powstaje w wyniku mechanicznego niszczenia podłoża skalnego przez lodowiec. Muton charakteryzuje się wydłużonym kształtem związanym z kierunkiem ruchu lodowca. Od strony napierającego lodu (stok proksymalny) ma powierzchnię bardziej płasko nachyloną, wygładzoną i porysowaną przez lodowiec (Fig. 13). Strona przeciwna do ruchu lodowca (stok dystalny) jest bardziej stroma i nieregularnie potrzaskana.

Na północ od Wyżniej Kopy znajduje się szeroka rynna glacjalna, którą odprowadzane są wody z Wielkiego Stawu, 


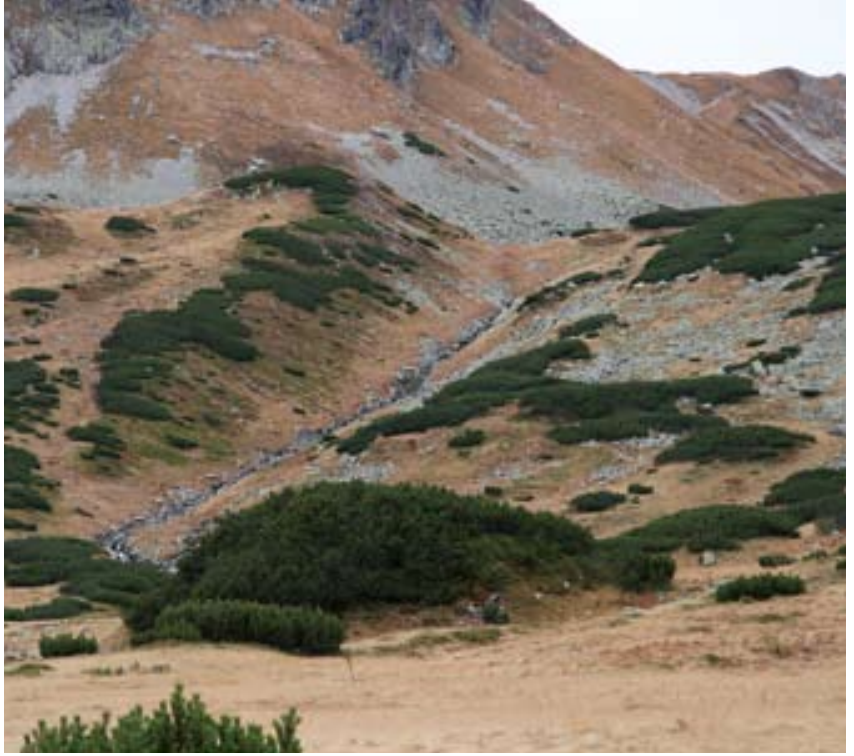

Fig. 14. Rynna wód proglacjalnych, ciągnąca się od podnóży zboczy Gładkiego Wierchu aż do zachodniego brzegu Wielkiego Stawu (fot. Madeja) - Proglacial channel extending from the footslope of the Gładki Wierch peak to the Wielki Staw pond (phot. Madeja).

a tym samym stanowią one początek wodospadu Siklawa. Dalej w kierunku północnym znajduje się kolejny garb mutonowy na wysokości 1719 m n.p.m., jednakże jest on zdecydowanie mniej czytelną formą niż wcześniej wspomniane kopy, natomiast nie jest porośnięty i posiada dobrze widoczny wygład lodowcowy. Wygład lodowcowy to powierzchnia litej skały wygładzona w wyniku szorowania o podłoże fragmentów skał przemieszczanych w spągowej części lodowca (Fig. 13).

Opisany rygiel opada ku Dolinie Roztoki progiem mierzącym 200 m wysokości. Dzisiejszy wygląd progu zmienił się nieznacznie od okresu ostatniego zlodowacenia. Jego część zachodnia jest cofnięta i rozcięta pięcioma rynnami polodowcowymi, które łączą się na wysokości 1545 m n.p.m. Centralna rynna to ta, która odprowadza wody z Wielkiego Stawu Polskiego, które natrafiając na stromą ścianę progu spadają $65 \mathrm{~m}$ niżej, tworząc największy w Tatrach wodospad - Siklawa. Strugi Siklawy płyną po wygładzonej ścianie progu, w której wyżłobione jest 7 rynien. W zależności od stanu wód Wielkiego Stawu Polskiego, wodospad wykorzystuje od 4 do 7 wspomnianych wcześniej rynien. $Z$ kolei część wschodnia progu jest mniej cofnięta od zachodniej oraz słabiej pocięta - występują tu tylko trzy rynny wycięte przez strugi wodne, które zostały przemodelowane przez masy lodowe (Klimaszewski, 1988).

W Dolinie Pięciu Stawów Polskich, poza formami powstałymi w wyniku bezpośredniego oddziaływania lodowca, występują także formy fluwioglacjalne. Najbardziej charakterystyczną formą tego typu jest rynna wód proglacjalnych (wypływających i uwolnionych z lodowca - posiadają znaczną siłę erozyjną), ciągnąca się od podnóży zboczy Gładkiego Wierchu aż do zachodniego brzegu Wielkiego Stawu (Fig. 1 i 14). Jej długość wynosi 1100 m, szerokość 30-50 m, a głębokość dochodzi do $30 \mathrm{~m}$. Obecnie rynna jest wykorzystywana przez wody Potoku Kołowego, który w basenie Wielkiego Stawu usypuje deltę o wysokości od $0,3-0,1 \mathrm{~m}$ nad poziomem jeziora zbudowaną z materiału żwirowego (Klimaszewski, 1988).

W obrębie Doliny Pięciu Stawów Polskich na uwagę zasługują inne formy peryglacjalne tzw. wały niwalne (moreny niwalne) (Dzierżek, Nitychoruk, 1986). Powstają one w wyniku akumulacji materiału skalnego osypującego się po zboczu pokrytym śniegiem, tworząc wypukłe formy występujące głównie u podnóża zbocza stożków osypiskowych (Jaroszewski i in., 1985).

Wały niwalne najlepiej widoczne są z żółtego szlaku na Szpiglasową Przełęcz, występują pod Miedzianym Kosturem, na Szpiglasowych Perciach, pod Gładkim Wierchem i Gładką Przełęczą (Dzierżek i in., 1987) (Fig. 6 i 15).

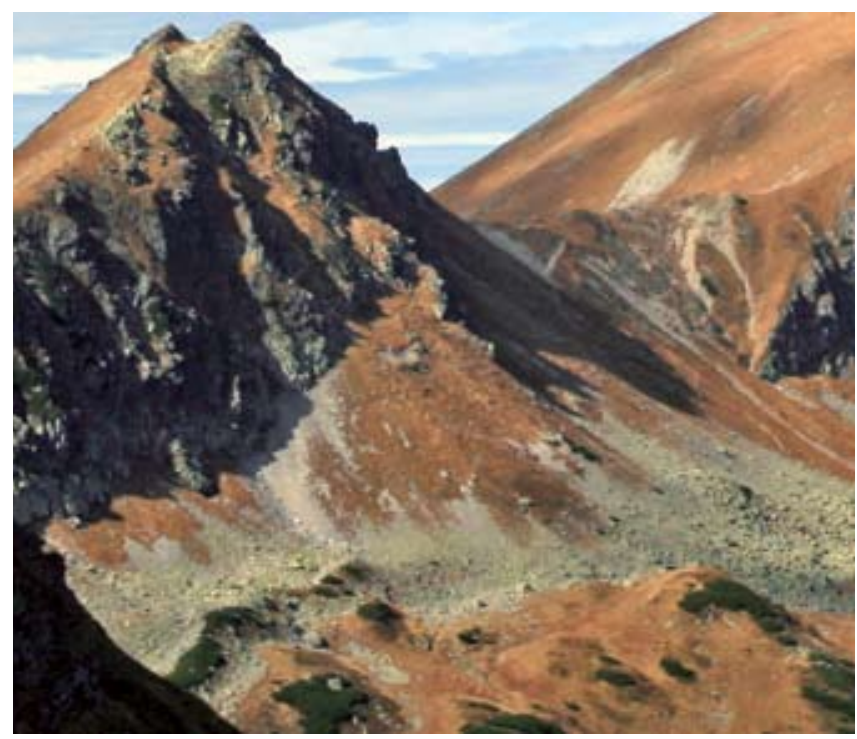

Fig. 15. Wały niwalne widoczne pod Gładkim Wierchem (fot. Mrowczyk) • Nival moraines at the footslope of the Gladki Wierch peak (phot. Mrowczyk)

\section{Podsumowanie}

Bogactwo form polodowcowych w Dolinie Pięciu Stawów Polskich wpływa dodatkowo na jej atrakcyjność turystyczną. Niestety tylko niewielki odsetek turystów zdaje sobie sprawę, że oglądany przez nich krajobraz to wynik działalności występujących tu w plejstocenie lodowców górskich. Dolina Pięciu Stawów Polskich ze względu na swoje położenie ma najbardziej dziki charakter w polskiej części Tatr Wysokich. Nie można tu dojechać bryczką ani wyjechać kolejką, należy jednak włożyć nieco wysiłku, aby się do niej dostać, efektem tego jest zdecydowana mniejsza ilość turystów niż w innych tatrzańskich dolinach. Wszystko to sprawia, że miejsce to jest pełne uroku niezależnie od pogody czy pory roku. Uzupełnieniem niezapomnianych wrażeń estetycznych, jakich dostarcza Dolina Pięciu Stawów Polskich, powinny być dyskretnie rozmieszczone w wybranych punktach widokowych tablice informujące o typie i genezie widocznych, licznych form polodowcowych, które tworzą ten niepowtarzalny i unikatowy krajobraz obserwowany i oddziałujący na turystów. To by pozwoliło na lepsze zrozumienie i pogłębienie wiedzy o geologii i procesach kształtujących powierzchnię Ziemi. 


\section{Summary}

\section{Post-glacial forms as geotouristic attractions of the Five Ponds Valley, the Tatra Mts.}

\author{
Paulina Mrowczyk, Grzegorz Madeja, \\ Marek Doktor
}

\section{Introduction}

The Tatra Mts. are an Alpine-type mountain range. The principal factors controlling the recent relief of the Tatras are Pleistocene valley glaciers, which have covered in the past $50 \%$ of the High Tatras and $21 \%$ of the Western Tatras. The Western Tatras glaciers were two times shorter than the High Tatras ones. Among the latter the longest $(14 \mathrm{~km})$ was the Białka Valley Glacier.

The perfect example of the post-glacial relief is the Five Ponds Valley located in the heart of the High Tatras. In this valley several glacial landforms can be distinguished: from huge cirques, through fossil rock glaciers, niches and troughs recently filled with water, and terminal moraines up to smaller forms as e.g. roches mountonnées or polished surfaces.

\section{Outline of geological structure}

The Tatras were formed during the Alpine orogeny when the African and European plates had collided. Folding and partial uplift took place in the Upper Cretaceous and was followed by the main, post-Oligocene uplift phase.

The principal structural unit of the Tatras is the crystalline core. It is composed of Carboniferous granites, which built the High Tatras and Devonian/Carboniferous gneisses, which dominate in the Western Tatras.

The northern slopes of the crystalline core are covered with sedimentary rocks. These are conglomerates and quartzitic sandstones followed by the High-Tatra Series and SubTatra Series. The High Tatra Series includes two nappes: the Czerwone Wierchy and the Giewont. It is bordered from the north by the Sub-Tatra Series, which has also two nappes: the Križna and the Choč. Both series are composed of Mesozoic carbonates and both have been thrusted from the south over the crystalline core. The amount of tectonic transport is estimated as about 5-15 kilometers for the High-Tatra Series and about 50-100 kilometers for the Sub-Tatra Series.

The Five Ponds Valley is located in the granitic crystalline core of the High Tatras. The Permian-Mesozoic and Tertiary rocks are absent, and the valley is filled with Quaternary post-glacial sediments.

\section{Glacier}

In the Tatras from three to five glaciations took place, corresponding to the Alpine Günz-Würm glacial epochs (in Polish nomenclature: Narew-Vistula glaciations).
For the shaping of recent relief in the Tatras the most important was the last glacial epoch, i.e. the Würm. Forms produced by earlier glaciations has been obliterated or rearranged.

According to recent reconstructions, the Würm glacier in the Five Ponds Valley was polythermal. It was probably 2,790 meters long and covered 2.4 square kilometers. Its highest point was located at 2,140 meters a.s.l. and the lowest one - at 1,690 meters a.s.1. Average thickness was 105 meters and maximum thickness reached 160 meters in the vicinity of the Zadni Pond. The glacier was an active firn field, which supplied the Roztoka Glacier - a branch of much larger Białka Valler Glacier.

Due to climate warming at the end of the Würm, the Tatras glaciers has retreated. In the Five Ponds Valley four phases of deglaciation took place between 13,000 and 9,000 years ago (see Fig. 2-5). At the third and fourth deglaciation stages the glacier evolved into the rock glacier.

\section{Post-glacial landforms}

After deglaciation several landforms generated by glacial erosion and accumulation processes have been exposed. The largest and best-preserved are cirques. In the Five Ponds Valley six cirques exist and additional one is located in the adjacent Buczynowa Valley.

The Pusta Valley Cirque (Fig. 1 \& 6) carved in the southern slopes of the Kozi Wierch peak is 980 meters long and 500 meters wide. The bottom of the cirque has two levels - the upper one (1,940-1,985 meters a.s.1.) is closed by a double wall of terminal moraine and descends with a rock step towards the lower level located at 1,880-1,850 meters a.s.l. The lower level also descends with 50-meters-high rock step to the main valley. The Pusta Valley is closed by moraine partly eroded in the central portion.

The Pod Kołem Valley (Fig. 1 \& 6) is a vast cirque, 1,350 meters long and only 350 meters wide. It was carved in the southern slopes of the Świnica and the Mały Kozi Wierch peaks. The headwall of the cirque is a niche in the Świnica Peak slope located at 2,050-2,150 meters a.s.l. It descends with 50-meters-high rock step towards the irregular, concaved bottom of the valley transformed into the cirque. Its bottom has two levels: the upper one is located at 1,990-1,950 meters a.s.l., in the northern margin of the Zadni Pond. The lower, more extended level descends to 1,900-1,850 meters a.s.l. and forms the bowl of the Zadni Pond, 31 meters deep and covering 6.5 hectares.

During the last (III and IV) retreat phases of the Five Ponds Valley Glacier the rock glaciers formed in both the Pod Kołem and the Pusta valleys. These glacier deposited well-visible rocky detritus blankets composed of unsorted, angular material with single blocks reaching volumes over 1 cubic meter.

The Czarna Lawka Cirque (Fig. $1 \& 8$ ) rimmed by the Czarna Ławka and the Niżny Kostur crests, it is a 450-meterslong, two-level niche of sloped bottom and mostly smooth walls. The upper level appears as a flat located at 1,900-1,880 
meters a.s.l. which descends with a rock step towards the lower level located at 1,830-1,790 meters a.s.l. The whole cirque wents down with a rock step towards the Czarny Staw trough and is covered in the lower part with a scree.

The Szpiglasowa Crique (Fig. $1 \& 9$ ) is rimmed by the Niżny Kostur, the Liptowskie Mury and the Szpiglasowy Wierch crests, and covers $800 \times 800$ meters area. The cirque has evolved from several, pre-glacial valleys transformed by firn and ice. It is a typical, multilevel cirque built by three cascading, semicircular amphitheatres. The irregular bottom of the upper amphitheater is located at 1,980-1,920 meters a.s.l. and has two moraine ridges. At the bottom of the middle amphitheater, located at 1,780-1,750 meters a.s.1., small roches mountonnées can be found. The lower amphitheater is poorly recognizable. Its bottom, located at 1,700 meters a.s.l. is flattened, polished and covered with a scree.

The Miedziane Cirque (Fig. $1 \& 9$ ) is cut in the northern slopes of the Miedziane Peak. It is 700 meters long and 350 meters wide. The outlet of the central gully is closed by a huge (250 meters high and 450 meters long) talus named the Hruby Piarg,. The bottom of the cirque, located at 1,800 meters a.s.l. is bordered from the north by 5-8-meters-high moraine ridge.

The Opalone Cirque (Fig. $1 \&$ 9) is carved in the northwestern slopes of the Miedziane and the Opalony Wierch peaks. It covers and area about $450 \times 450$ meters. Its bottom, located at 1,740-1,780 meters a.s.1. is closed by 10-20-metershigh, semicircular terminal moraine.

The Buczynowa Valley Cirque (Fig. $1 \& 10$ ) is the most typical of the Tatra Mts. and, simultaneously, it is a typical example of the hanging valley. It is 950 meters long and 400 meters wide. The two-levels cirque is surrounded by craggy walls of the Kozi Wierch, Granaty, Orla Baszta and Wielka Buczynowa peaks. The cirque originated from transformation of several gullies by glacier action. The concave, upper level, located at 1,790-1,800 meters a.s.1. is closed by a double ridge of terminal moraine, up to 30 meters high, and descends with rock step towards the lower level, located at 1,695-1,740 meters a.s.l. and closed by 10 -meters-high terminal moraine. The whole cirque opens down to the Roztoka Valley with 260-meters-high rock step.

In the Five Ponds Valley six main ponds are known, from which five fill the post-glacial bowls and troughs. Only the Wole Oko pond is presumably unrelated to the glacial processes.

The Zadni Staw bowl (Fig. 1 \& 6) is rimmed with 15-meters-high, steep, craggy walls. Total depth of the bowl is 40 meters. From the south the bowl is closed by a rock riegel on which 6-15-meters-high terminal moraine was deposited.

The Wielki Staw Polski trough (Fig. 1 \& 9) is 998 meters long, 425 meters wide and 79 meters deep. It has originated from the confluence of glacier tongues descending from the Pod Kołem and the Pusta valleys, and from the Czarna Ławka and the Szpiglasowa cirques. From the northeast the pond is dammed by $8-25$-meters-high ridge of terminal moraine.

The Przedni Staw bowl (Fig. 1 \& 9) is 396 meters long, 306 meters wide and 35 meters deep. It was formed by confluence of glaciers advancing from the Miedziane and the Opalony cirques. Water table is located at 1,668 meters a.s.1.

The Maly Staw pond (Fig. $1 \&$ 9), located at 1,668 meters a.s.1. is 68 meters long, 36 meters wide and 2.1 meters deep. It is a kettle pond located between the Wielki Staw and the Przedni Staw ponds, at the flat built of ground moraine deposits.

The Czarny Staw trough (Fig. $1 \& 8$ ) was formed by confluence of glaciers descending from the Pod Kołem and the Pusta valleys, and from the Czarna Ławka cirque. Water table is located at 1,665 meters a.s.l. Due to the action of glacier descending from the Pusta valley the trough bottom was strongly concaved.

The Wole Oko is a small pond located at the foreland of terminal moraine of the Zadni Staw Glacier. It is located in an elongated, 15-meters-deep depression of steep, commonly craggy walls. Pond is supplied by waters draining the Zadni Staw pond. The origin of this pond is controversial.

The Five Ponds Valley is closed by 1,400-meters-long rock riegel (Fig. 11) oriented obliquely to the axis of the valley. It includes two segments: the southeastern and the northwestern, separated by the Wyżnia Kopa Peak (1,772 meters a.s.1.). Both the Wyżnia Kopa and the Niżnia Kopa (1,711 meters a.s.1.) peaks are huge roches mountonées of distinct, proximal and distal slopes. North from the Wyżnia Kopa Peak there is a wide, post-glacial channel which drains the Wielki Staw pond and supplies water for the Siklawa waterfall (Fig. 1, 11 \& 12).

The riegel descends to the Roztoka Valley with a 200meters-high rock step dissected by numerous chutes. Waters drained from the Wielki Staw Polski pond flow through the central channel and supply the tallest waterfall in Poland - the Siklawa (65 meters).

Apart from landforms produced by direct action of glaciers, the Five Ponds Valley hosts also fluvioglacial forms. The most typical is a proglacial channel extending from the foot of the Gładki Wierch peak until the western shore of the Wielki Staw pond. It is 1,100 meters long, 30-50 meters wide and up to 30 meters deep. Recently, the channel is used by waters of the Kołowy Stream. (Fig. 1, 6 \& 14).

In the Five Ponds Valley common are nival moraines located mainly at the southern footslopes of the valley. Such landforms are best-seen from the yellow trail leading to the Szpliglasowa Col and occur beneath the Miedziany Kostur, at the Szpiglasowe Perci crest, beneath the Gładki Wierch peak and the Gładka Col (Fig.6 \& 15).

\section{Conclusions}

Abundance of post-glacial landforms in the Five Ponds Valley increases the attractiveness of this part of the Tatra Mts. However, only a fraction of tourists who visit this area 
realizes that the landscape they admire is a result of the action of Pleistocene glaciers. The valley is a true wilderness in the Polish part of the High Tatras. It can be reached only by hiking, which discourages many potential visitors. Hence, the valley trails are not overcrowded and this site is charming at any weather conditions and in any part of the year. Additional advantage for the tourists could be information boards displaying the observed landforms and providing simple explanations of the origin and formation of glacial landforms.

\section{Literatura (References)}

Atlas Tatrzańskiego Parku Narodowego (red. Trafas K.), 1985. Wojskowe Zakłady Kartograficzne.

Bac-Moszaszwili M., 1992. Tatry Polskie. Wydawnictwa Geologiczne, 158 pp.

Dobiński W., 1994. Lodowce gruzowe. Czasopismo geograficzne, LXV: $109-123$.

Dzierżek J. , Nitychoruk J., 1986. Types of fossil rock glaciers in the Polish High Mts. Bull. Polish Acad. Sc., Earth Science.

Dzierżek J., Lindner L., Nitychoruk J., 1987. Rzeźba i osady czwartorzędowe Doliny Pięciu Stawów Polskich (Tatry Wysokie). Przegląd Geologiczny, 35: 8-15.

Felisiak I., 2008. The Tatra - nappes and landscapes. Geoturystyka, 13: 75-87.

Gądek B., 1998. Würmskie zlodowacenie Tatr w świetle rekonstrukcji lodowców wybranych dolin na podstawie prawidłowości glacjologicznych. Prace naukowe UŚL, 1741: 1-152.
Jaroszewski W., Leszek M., Radomski A.; 1985. Słownik geologii dynamicznej. Wydawnictwo Geologiczne, Warszawa. 308 pp.

Klimaszewski M., 1988. Rzeźba Tatr Polskich. Państwowe Wydawnictwo Naukowe, 667 pp.

Mapa geologiczna Tatr Polskich 1:30 000, 1979. Wydawnictwo Geologiczne, Warszawa.

Michalik A., 1951. Regionalna geologia Polski - stratygrafia. Polskie Wydawnictwo Geologiczne, 206 pp.

Mojski J.E., 2005. Ziemie Polskie w czwartorzędzie: zarys morfogenezy. PIG, Warszawa. 404 pp.

Mrowczyk P., Madeja G., 2008. Formy polodowcowe jako atrakcje geoturystyczne Doliny Pięciu Stawów Polskich, niepublikowana praca magisterska (AGH Kraków, Wydział Geologii, Geofizyki i Ochrony Środowiska).

Passendorfer E., 1983. Jak powstały Tatry. Wydawnictwo Geologiczne, 286 pp. 